Vol. 1, No. 2, 2019

\title{
PENERAPAN STRATEGI PEMBELAJARAN TIME TOKEN UNTUK MENINGKATKAN HASIL BELAJAR MATEMATIKA SISWA KELAS X SMKN 2 SINGOSARI
}

\author{
Saktia Oktaviani $^{1}$, Sri Hariyani ${ }^{2}$, Yuniar Ika Putri Pranyata ${ }^{3}$ \\ Pendidikan Matematika, Universitas Kanjuruhan Malang ${ }^{1,2,3}$ \\ saktiaoktav@gmail.com¹, srihariyani@unikama.ac.id ${ }^{2}$, yuniar.mat@unikama.ac.id ${ }^{3}$
}

\begin{abstract}
Abstrak. Berdasarkan observasi awal yang dilakukan peneliti selama magang, beberapa siswa beranggapan bahwa matematika merupakan pelajaran yang sulit, tidak menarik dan membuat pusing. Hal ini dapat mempengaruhi hasil belajar siswa. Strategi pembelajaran yang inovatif diperlukan untuk meningkatkan hasil belajar matematika. Penelitian ini bermaksud mengkaji penerapan strategi pembelajaran Time Token untuk meningkatkan hasil belajar matematika. Penelitian ini merupakan penelitian tindakan kelas yang bertujuan untuk mendeskripsikan langkah-langkah penerapan strategi Time Token yang dapat meningkatkan hasil belajar matematika pada pokok bahasan Matriks kelas X SMKN 2 Singosari tahun ajaran 2018/2019. Pendekatan yang digunakan adalah pendekatan kualitatif. Subjek penelitian adalah siswa kelas X SMKN 2 Singosari tahun ajaran 2018/2019 berjumlah 36 siswa.Sumber data diperoleh dari observasi, catatan lapangan, tes, dan dokumentasi. Metode pengumpulan data meliputi (1) tes, (2) observasi, dan (3) dokumentasi. Analisis data dilakukan dengan cara reduksi data, penyajian data, dan penarikan kesimpulan. Pengecekan keabsahan data dengan cara ketekunan pengamat, triangulasi dan pemeriksaan sejawat melalui diskusi. Tahap-tahap dalam penelitian meliputi tahap awal dengan penyampaian apersepsi, motivasi dan tujuan pembelajaran. Tahap inti yaitu (1) Orientasi, (2) Mengorganisasikan, (3) Membimbing, (4) Presentasi, (5) Analisis dan Evalusi, serta (6) Pemberian strategi Time Token. Tahap akhir yaitu motivasi siswa untuk belajar. Hasil penelitian aktivitas siswa pada tindakan I yaitu pada pertemuan 1 mendapatkan persentase ratarata $81,96 \%$ dan pada pertemuan 2 mendapatkan persentase rata-rata $78,96 \%$, sedangkan aktivitas siswa pada tindakan II yaitupada pertemuan 1 mendapatkan persentase rata-rata $88,89 \%$ dan pada pertemuan 2 mendapatkan persentase rata-rata $91,075 \%$. Hasil analisis data dalam penelitian yaitu persentase ketuntasan hasil tes siswa pada tindakan I mencapai $72,22 \%$. Sedangkan pada tindakan II mencapai persentase $86,1 \%$. Dengan demikian dapat disimpulkan bahwa penggunaan strategi pembelajaran Time Token dapat meningkatkan hasil belajar siswa kelas X SMKN 2 Singosari.
\end{abstract}

Kata Kunci: Strategi Pembelajaran; Time Token; hasil belajar

\section{PENDAHULUAN}

Pembelajaran di sekolah terdiri atas beberapa ilmu pendidikan, salah satunya adalah matematika. Matematika merupakan pelajaran yang penting karena berguna bagi kehidupan sehari-hari. Matematika mengajarkan siswa untuk berpikir sistematis, logis, dan abstrak. Matematika akan menjadikan siswa berlatih menyelesaikan sesuatu sesuai dengan urutan, tahapan, dan langkah-langkah suatu penyelesaian, selain itu dengan belajar matematika maka siswa akan berlatih menyelesaikan masalah sesuai dengan kemampuan penalarannya. Nugroho (2017:198) berpendapat bahwa matematika menjadikan siswa berlatih menyelesaikan masalah dalam kehidupan sehari-hari, matematika juga memiliki peranan yang penting sebagai dasar logika atau penalaran dan penyelesaian kuantitatif yang digunakan dalam pelajaran lainnya. 
Namun, kenyataan di lapangan menunjukkan bahwa banyak siswa yang kesulitan memahami materi matematika. Berdasarkan observasi awal yang dilakukan peneliti selama magang di kelas X SMKN 2 Singosari, beberapa siswa SMKN 2 Singosari beranggapan bahwa matematika merupakan pelajaran yang sulit, tidak menarik dan membuat pusing. Selain itu, metode pengajaran guru masih cenderung monoton. Hal ini menyebabkan banyak siswa yang bersifat pasif, baik untuk bertanya ataupun mengerjakan tugas yang diberikan oleh guru. Dalam proses pembelajaran hanya beberapa siswa yang betul-betul aktif di dalam kelas.

Gejala-gejala yang muncul di atas disebabkan oleh beberapa faktor, salah satunya adalah pemilihan metode mengajar. Guru matematika mengajar dengan menggunakan metode ceramah. Metode ceramah yaitu metode belajar yang digunakan untuk menyampaikan pelajaran yang sesuai dengan tujuan pembelajaran, sedangkan penerapan metode ceramah hanya terpusat pada guru, sehingga siswa cenderung pasif dan sulit untuk mengembangkan potensi yang ada dalam dirinya (Rusman, 2012:25). Kondisi siswa yang kurang aktif juga dapat menyebabkan interaksi siswa dan guru berkurang (Hariyani et al., 2019). Kemampuan menganalisis dan menyelesaikan soal rendah, sehingga apabila ada tugas, siswa cenderung mencontoh pekerjaan temannya. Selain itu, metode ceramah yang dijalankan terus menerus dapat mengakibatkan siswa merasa bosan dan tidak bersemangat, sehingga mengakibatkan hasil belajar berada di bawah KKM. Menurut Suryani dan Rosi (2014:2) untuk dapat meningkatkan hasil belajar siswa dan menjadikan siswa aktif membangun pengetahuan perlu diterapkan strategi pembelajaran inovatif agar siswa dapat berfikir mandiri.

Berdasarkan masalah tersebut, peneliti berpendapat perlunya dilakukan perbaikan proses pembelajaran. Selain metode pembelajaran, cara lain untuk meningkatkan hasil belajar siswa dalam pembelajaran matematika adalah penggunaan strategi pembelajaran. Salah satu strategi pembelajaran yang dapat digunakan adalah strategi Time Token. Penerapan strategi Time Token dalam pembelajaran matematika dimaksudkan agar setiap siswa bertanggung jawab dan siswa akan termotivasi untuk mengerjakan tugas, sehingga siswa tidak lagi cenderung pasif dalam proses pembelajaran, selain itu strategi pembelajaran Time Token dapat meningkatkan komunikasi siswa dalam pembelajaran matematika (Fahrudin, 2014:5). Strategi Time Token merupakan model belajar dengan ciri adanya tanda waktu atau batasan waktu dan struktur yang dapat digunakan untuk mengajarkan keterampilan, menghindari siswa mendominasi pembicaraan atau siswa diam sama sekali. Strategi Time Token dalam pembelajaran matematika memastikan setiap siswa mendapatkan kesempatan untuk berperan serta dalam proses belajar mengajar.

Berdasarkan penelitian sebelumnya tentang penerapan strategi Time Token yaitu penelitian Nikmah (2012), diperoleh data sebelum penelitian mencapai $12,82 \%$, pada putaran I meningkat menjadi $28,57 \%$, pada putaran II mencapai $41,67 \%$, dan pada putaran III mencapai $55,26 \%$. Keberanian siswa mengungkapkan ide atau gagasan mereka juga mengalami peningkatan pada setiap putaran. Sebelum penelitian, keaktifan siswa mencapai 5,13\%, pada putaran I meningkat menjadi 11,43\%, pada putaran II mencapai16,67\%, dan pada putaran III mencapai $28,95 \%$. Keaktifan siswa dalam mengerjakan soal di depan kelas tanpa harus disuruh oleh guru juga mengalami peningkatan. Sebelum penelitian, keaktifan siswa mencapai 15,38\%, pada putaran I mencapai $22,86 \%$, pada putaran II mencapai $27,78 \%$, dan pada putaran III mencapai $36,84 \%$. Keaktifan siswa dalam menjawab pertanyaan yang diberikan oleh guru semakin meningkat. Sebelum dilakukan penelitian mencapai $12,82 \%$, pada putaran I mencapai $34,29 \%$, pada putaran II mencapai 50\%, dan pada putaran III mencapai 68,42\%. Sedangkan penelitian yang diteliti oleh Fahrudin (2014) menunjukkan bahwa penerapan strategi pembelajaran Time Token dapat meningkatkan kemampuan komunikasi matematika siswa. Aspek pertama memiliki kemampuan lisan yaitu mampu bertanya, menjawab, dan 
menyimpulkan. Sebelum penelitian, ada 8 siswa $(26,6 \%)$, sesudah penelitian pada siklus I ada 18 siswa (60\%) dan pada siklus II ada 25 siswa (83,33\%). Aspek kedua mampu menggunakan simbol-simbol matematika secara tepat. Sebelum penelitian, ada 5 siswa $(16,67 \%)$, sesudah penelitian pada siklus I ada 20 siswa $(66,67 \%)$ dan pada siklus II ada 24 siswa (80\%). Aspek ketiga mampu mengubah permasalahan ke dalam ilustrasi penyelesaian. Sebelum penelitian ada 7 siswa (23,33\%), sesudah penelitian pada siklus I ada 15 siswa (50\%), dan pada siklus II ada 22 siswa $(73,33 \%)$. Aspek yang keempat mampu menjelaskan solusi matematika, sebelum penelitian ada 6 siswa (20\%), setelah penelitian pada siklus I ada 21 siswa $70 \%$ dan pada siklus II ada 26 siswa $(86,67 \%)$.

Perbedaan penelitian ini dan penelitian sebelumnya yaitu penelitian sebelumnya yang dilakukan oleh Nikmah (2012), strategi Time Token diterapkan untuk meningkatkan keaktifan siswa. Penelitian Fahrudin (2014), strategi Time Token diterapkan untuk meningkatkan komunikasi belajar sedangkan pada penelitian ini strategi Time Token diterapkan untuk meningkatkan hasil belajar matematika. Berdasarkan uraian di atas dapat disimpulkan bahwa strategi pembelajaran Time Token merupakan strategi pembelajaran yang dapat meningkatkan hasil belajar matematika siswa kelas X SMKN 2 Singosari.

\section{METODE PENELITIAN}

Penelitian ini dirancang dengan menggunakan penelitian tindakan kelas (PTK). Pendekatan yang digunakan dalam penelitian ini adalah pendekatan kualitatif. Penelitian ini mendeskripsikan proses pembelajaran dan hasil belajar, kemudian data disajikan secara deskriptif atau berupa kata-kata atau pernyataan-pernyataan yang diperoleh melalui dokumen, angket, observasi, hasil tes dan catatan lapangan.

Penelitian ini dilakukan di SMKN 2 Singosari Kabupaten Malang Tahun ajaran 2018/2019. Sedangkan subjek penelitian ini adalah siswa kelas X yang berjumlah 36 orang. Materi dalam penelitian ini adalah Matriks. Sumber data pada penelitian ini adalah (1) hasil pekerjaan siswa pada saat mengerjakan soal tes akhir, (2) hasil observasi, dan (3) hasil catatan lapangan. Siswa kelas X berjumlah 36 orang terdiri atas 27 laki-laki dan 9 perempuan. Penelitian ini menggunakan seluruh siswa sebagai subjek penelitian.

Instrumen pembelajaran yang digunakan dalam penelitian ini antara lain: (1) RPP, (2) LKPD, dan (3) Skenario Pembelajaran. Sedangkan metode pengumpulan data yaitu (1) tes, (2) observasi, dan (3) dokumentasi. Analisis data yang digunakan dalam penelitian adalah (1) reduksi data, (2) penyajian data, dan (3) penarikan kesimpulan. Pengecekan keabsahan data dilakukan dengan cara ketekunan pengamat, triangulasi dan pemeriksaan sejawat melalui diskusi. Tahap-tahap dalam penelitian meliputi tahap awal dengan penyampaian apersepsi, motivasi dan tujuan pembelajaran. Tahap inti yaitu (1) Orientasi, (2) Mengorganisasikan, (3) Membimbing, (4) Presentasi, (5) Analisis dan Evalusi, serta (6) Pemberian strategi Time Token. Tahap akhir dilakukan dengan memotivasi siswa untuk belajar.

\section{HASIL DAN PEMBAHASAN}

Pada pra tindakan diperoleh data nilai terakhir siswa yang akan digunakan sebagai data awal untuk mengetahui kemampuan siswa. Nilai rata-rata seluruh siswa terlihat pada Tabel 1. 
Tabel 1. Nilai Tes Siswa Sebelum Tindakan

\begin{tabular}{lc}
\hline \multicolumn{1}{c}{ Keterangan } & Jumlah \\
\hline Jumlah siswa & 36 \\
Siswa yang memenuhi KKM & 17 \\
Rata-rata kelas X & 66 \\
Persentase ketuntasan & $47,22 \%$ \\
\hline
\end{tabular}

Dari Tabel 1 terlihat bahwa nilai rata-rata kelas adalah 66. Kriteria ketuntasan minimal yang digunakan di sekolah yaitu 75 . Siswa yang mendapat nilai $\geq 75$ sebanyak 17 siswa dengan persentase ketuntasan 47,22\%, ketuntasan ini belum mencapai ketuntasan minimum yang ditentukan oleh sekolah dan yang ditetapkan oleh peneliti.

Pada tindakan I, aktivitas guru pada pertemuan pertama mendapat persentase dari observer I $85 \%$, dari observer II mendapat persentase $82,5 \%$. Pada pertemuan II observer I mendapat persentase $85,71 \%$, dari observer II mendapat persentase $85,71 \%$. Persentase rata-rata aktivitas guru pada tindakan I 84,73\%.Perolehan skor pada pertemuan 1 dan pertemuan 2 dapat dilihat pada Gambar 1 berikut.

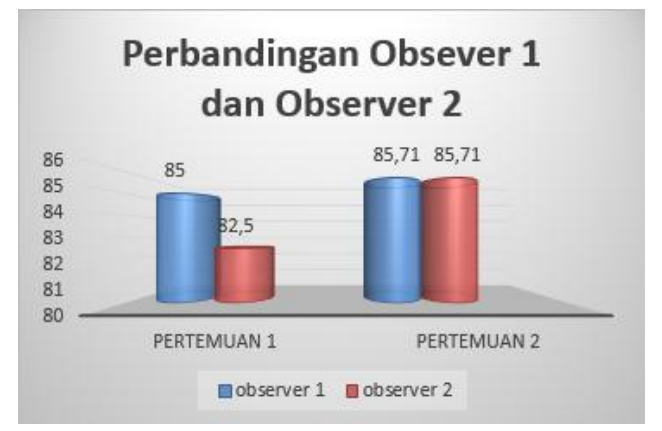

Gambar 1. Perbandingan Aktivitas Siswa Observer 1 dan Observer 2

Hasil pengamatan aktivitas siswa pada pertemuan 1 mendapat persentase dari observer I $83,33 \%$, dari observer II mendapat persentase 80,56\%. Pada pertemuan 2 persentase dari observer I mendapat persentase 78,57\%, dari observer II mendapat persentase $75 \%$. Persentase rata-rata aktivitas siswa pada tindakan I 79,35\%. Perolehan skor pada pertemuan 1 dan pertemuan 2 dapat dilihat pada Gambar 2 berikut.

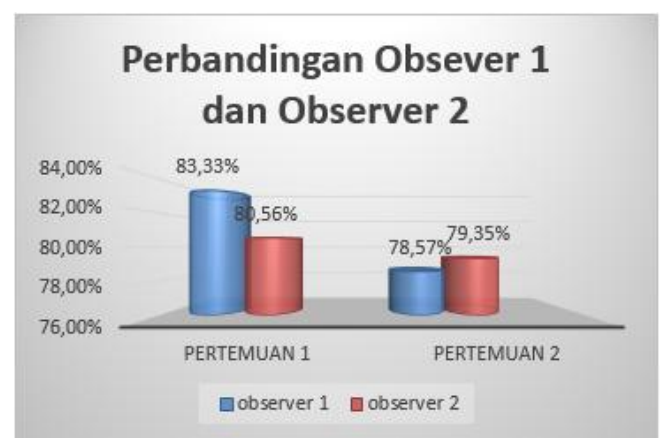

Gambar 2. Perbandingan Aktivitas Siswa Observer 1 dan Observer 2

Hasil belajar siswa pada tindakan I menunjukkan bahwa rata-rata hasil tes siswa $72,22 \%$. Hasil belajar siswa belum mencapai kriteria keberhasilan yang ditetapkan peneliti yaitu $\geq 75 \%$. Namun, hasil tes siswa meningkat dari sebelum diadakan tindakan. Presentase hasil belajar siswa pada saat pra tindakan dan tindakan I dapat dilihat pada Gambar 3 berikut. 


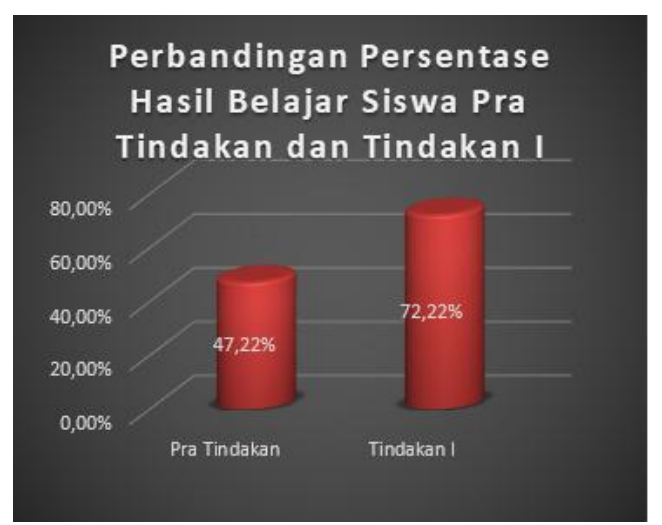

Gambar 3 Perbandingan Persentase Nilai Siswa Pra Tindakan dan Tindakan I

Nilai rata-rata siswa setelah tindakan meningkat dari hasil pra tindakan nilai rata-rata 66 dengan total siswa yang tuntas 17 siswa sedangkan pada tindakan I nilai rata-rata siswa 70,5 dengan total siswa yang tuntas sebanyak 26 siswa. Hal ini dapat dilihat pada Gambar 4 berikut.

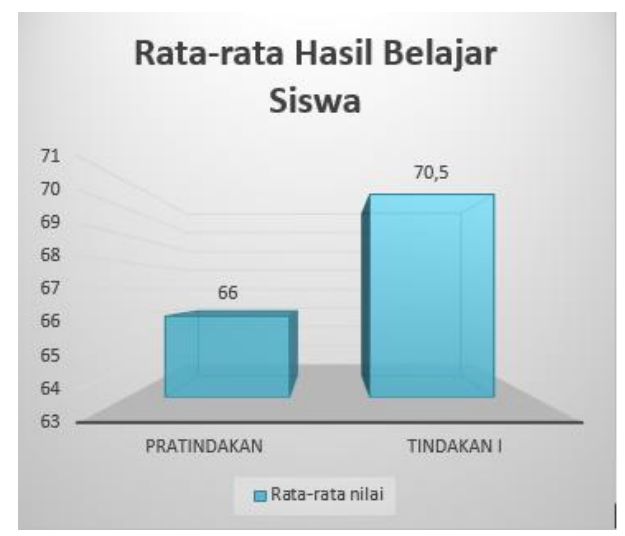

Gambar 4 Perbandingan Rata-Rata Hasil Belajar Siswa Pra Tindakan dan Tindakan I

Jika hasil belum mencapai target maka tindakan penelitian harus dilanjutkan. Catatan yang diperoleh peneliti dari tindakan I antara lain: (1) Peneliti harus lebih fokus pada siswa yang mempunyai kemampuan yang kurang, (2) Peneliti harus memperhatikan siswa saat pelaksanaan pembelajaran berlangsung terutama siswa yang berada pada bangku paling belakang dan siswa yang belum aktif akan ditunjuk untuk melakukan presentasi, (3) Peneliti harus memotivasi siswa agar bertanya kalau ada yang belum jelas, (4) Peneliti harus lebih tegas dalam menertibkan siswa, (5) Peneliti harus memberikan arahan mengenai manfaat berkelompok secara heterogen, agar siswa mau menuruti perintah peneliti, dan (6) Peneliti harus memberikan motivasi dan semnagat agar siswa tidak malas dan mengantuk dalam pembelajaran.

Pada tindakan II, aktivitas guru pada pertemuan pertama mendapat persentase dari observer I 90\%,dari observer II mendapat persentase $87,5 \%$. Pada pertemuan II dengan strategi Time Token dari observer I mendapat persentase $89,3 \%$, dari observer II mendapat persentase $92,86 \%$. Persentase rata-rata aktivitas guru pada tindakan II 89,92\%. Perolehan skor pada pertemuan 1 dan pertemuan 2 dapat dilihat pada Gambar 5 berikut. 


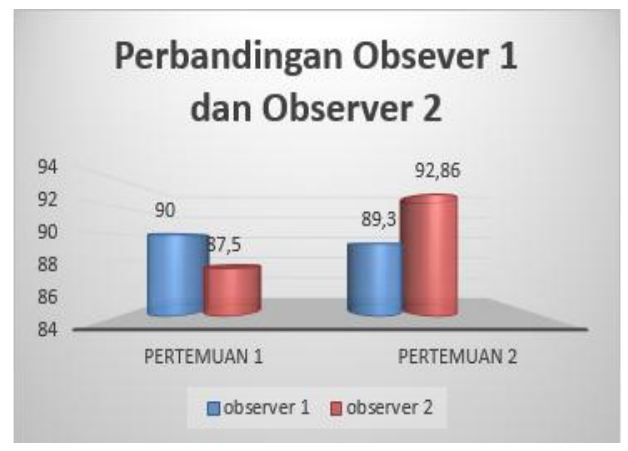

\section{Gambar 5 Perbandingan Aktivitas Siswa Observer 1 dan Observer 2}

Hasil pengamatan aktivitas siswa mendapat persentase dari observer I $88,89 \%$, dari observer II mendapat persentase $88,89 \%$. Pada pembelajaran dengan menerapkan strategi Time Token dari observer I mendapat persentase $89,29 \%$, dari observer II mendapat persentase $92,86 \%$. Persentase rata-rata aktivitas siswa pada tindakan II 89,99\%.Perolehan skor pada pertemuan 1 dan pertemuan 2 dapat dilihat pada Gambar 6 berikut.

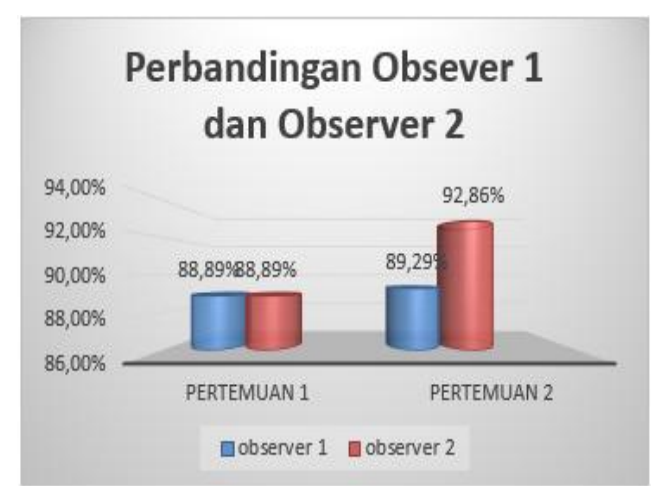

\section{Gambar 6 Perbandingan Aktivitas Guru Observer 1 dan Observer 2}

Persentase jumlah siswa yang memenuhi KKM meningkat dari tindakan I dan tindakan II. Tindakan I 72,22\% dan tindakan II $86,1 \%$. Berikut peneliti tampilkan grafik rata-rata hasil belajar pada saat tindakan I dan tindakan II dapat dilihat pada Gambar 7 berikut.

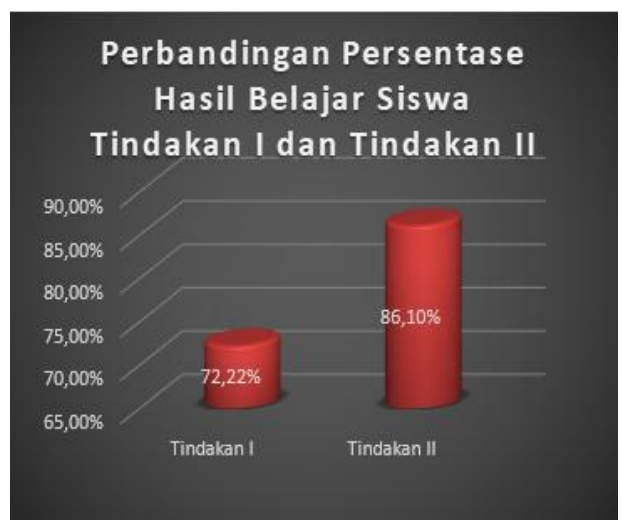

Gambar 7 Perbandingan Persentase Nilai Siswa Tindakan I dan Tindakan II

Nilai rata-rata pada tindakan I yaitu 70,5 dengan jumlah siswa yang tuntas sebanyak 26 siswa dan pada tindakan II 80,5 dengan jumlah siswa yang tuntas pada tindakan II sebanyak 31 siswa dapat dilihat pada Gambar 8 berikut. 


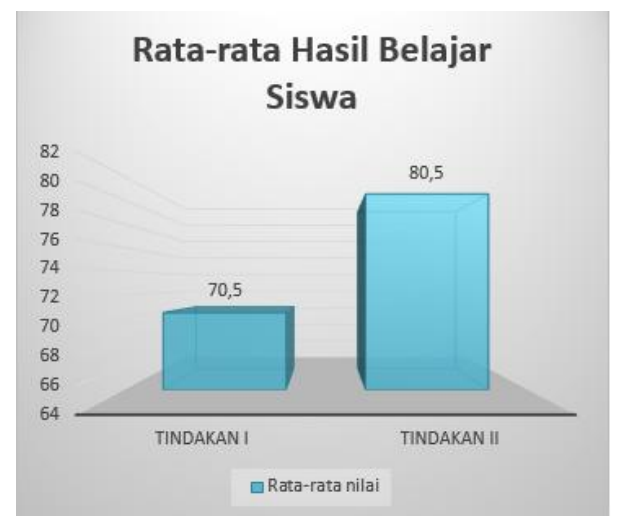

Gambar 8 Perbandingan Rata-Rata Hasil Belajar Siswa Tindakan I dan Tindakan II

Hasil penelitian pada tindakan II menunjukan bahwa aktivitas guru dan siswa selama proses pembelajaran lebih baik dari tindakan I. Berdasarkan hasil analisis ketuntasan belajar dapat tercapai, analisis aktivitas guru dan siswa juga tercapai dengan kriteria sangat baik. Dengan demikian kriteria keberhasilan tindakan II telah tercapai. Hal ini dapat disimpulkan bahwa penerapan strategi Time Token dapat meningkatkan hasil belajar matematika siswa. Selain itu juga dapat meningkatkan hasil kemampuan berpikir kritis siswa dalam menyelesaikan masalah pada soal (Latifah, 2014:20).

Strategi pembelajaran Time Token meliputi kegiatan awal, kegiatan inti, dan penutup. Pada kegiatan awal, pembelajaran diawali dengan salam dan apersepsi. Peneliti memberikan apersepsi dengan menanyakan soal pada pertemuan sebelumnya. Kegiatan ini dilakukan agar siswa mengingat kembali materi pada pertemuan sebelumnya.

Guru memberikan motivasi dan menyampaikan tujuan pembelajaran. Tujuan pembelajaran disampaikan kepada siswa untuk memberikan informasi terkait materi yang akan dipelajari siswa.Hal ini sejalan dengan pendapat Abdullah (2012:220) yang menyatakan bahwadengan adanya tujuan pembelajaran maka akan mempengaruhi kegiatan pengajaran yang dilakukan oleh guru, dan secara langsung berpengaruh terhadap kegiatan belajar siswa. Hal ini penting dilakukan sesuai dengan konsep belajar bahwa tujuan yang jelas akan dapat membantu belajar siswa.

Guru membagi siswa dalam bentuk kelompok, setiap kelompok terdiri dari 6 siswa. Siswa bersama kelompok mendiskusikan lembar kerja peserta didik yang telah diberikan oleh peneliti. Guru menunjuk salah satu siswa dalam kelompok secara acak untuk mempresentasikan hasil diskusi kelompok. Pada tahap akhir guru bersama siswa menganalisis hasil pemecahan masalah yang disajikan untuk mendapat kesimpulan jawaban yang benar.

Setelah pembelajaran kelompok dengan mendiskusikan lembar kerja peserta didik, dipertemuan selanjutnya guru memberikan strategi pembelajaran Time Token. Pemakaian strategi pembelajaran Time Token untuk membangkitkan keinginan, minat dan semangat siswa dalam mengikuti pembelajaran. Hal ini sejalan dengan pendapat Nurdyansyah dan Toyiba (2018:5) bahwa strategi pembelajaran akan membangkitkan rasa senang dan gembira bagi siswa dan memperbarui semangat siswa dalam belajar. Strategi pembelajaran Time Token dalam penelitian ini merupakan model belajar dengan ciri adanya tanda waktu atau batasan waktu dan struktur yang dapat digunakan untuk mengajarkan keterampilan, menghindari siswa mendominasi pembicaraan atau siswa diam sama sekali. Strategi Time Token dalam penelitian ini dilakukan dengan cara berkelompok. Hal ini sejalan dengan pendapat Kencana (2013:6) pembelajaran Time Token dilakukan secara berkelompok agar dapat mengatasi hambatan pemerataan kesempatan yang sering mewarnai kerja kelompok. Adapun langkah-langkah pembelajaran dengan menerapkan strategi Time Token yaitu kondisikan kelas untuk melakukan 
diskusi (Cooperative Learning/CL) yang dibagi menjadi 6 kelompok, masing-masing kelompok terdiri dari 6 siswa selanjutnya, siswa diberi kupon berbicara.Jika sudah selesai mengerjakan berdasarkan waktu yang ditetapkan, guru memberikan waktu \pm 30 detik per kupon pada tiap siswa untuk membacakan jawabannya. Jika lebih dari 30 detik siswa tidak mampu menjawab maka kelompok lain diperbolehkan untuk membacakan jawaban. Bila telah selesai berbicara, kupon yang dipegang siswa diserahkan kepada guru. Tiap siswa akan diberi nilai jika jawaban benar sesuai waktu yang digunakan. Nilai dari tiap siswa tersebut akan ditotal menjadi nilai kelompok. Siswa yang telah habis kuponnya tidak boleh berbicara lagi, sedangkan siswa yang masih memegang kupon harus berbicara sampai kuponnya habis. Hal ini sependapat dengan Huda (2013:242) langkah-langkah strategi pembelajaran Time Token yaitu guru memberikan sejumlah kupon berbicara dengan waktu \pm 30 detik per kupon pada tiap siswa selanjutnya, guru meminta siswa menyerahkan kupon terlebih dahulu sebelum berbicara atau memberi komentar. Siswa setiap tampil berbicara satu kupon. Siswa dapat tampil lagi setelah bergiliran dengan siswa lainnya. Siswa yang telah habis kuponnya tidak boleh berbicara lagi. Siswa yang masih memegang kupon harus berbicara sampai semua kuponnya habis. Demikian seterusnya hingga semua anak bicara. Pada kegiatan penutup siswa dan guru menyimpulkan materi yang diperoleh pada pertemuan pertama dan pertemuan kedua. Dengan menyimpulkan materi diharapkan siswa mampu mempertahankan ingatan terhadap pembelajaran dengan baik.

Proses pembelajaran menggunakan strategi Time Token pada tindakan I dan tindakan II, keduanya dapat dikategorikan baik dan sangat baik. Persentase observasi aktivitas guru pada tindakan I pertemuan $183,75 \%$ dan pertemuan $285,71 \%$. Pada tindakan II pertemuan $188,75 \%$ dan pertemuan $291,08 \%$. Sedangkan persentase aktivitas siswa pada tindakan I pertemuan 1 $81,96 \%$ dan pertemuan $278,96 \%$. Pada tindakan II pertemuan $188,89 \%$ dan pertemuan 2 91,07\%. Dari hasil tersebut menunjukkan persentase proses pembelajaran aktivitas guru dan aktivitas siswa, dapat dikategorikan baik dan sangat baik. Peningkatan juga terjadi pada hasil belajar siswa, dengan menerapkan strategi Time Token yang diterapkan pada tindakan I dan tindakan II dengan persentase ketuntasan yang telah diperoleh berada di atas nilai ketuntasan pada indikator keberhasilan tindakan yang ditetapkan peneliti yaitu lebih $75 \%$ siswa telah mencapai ketuntasan dengan KKM minimal 75.

Kendala yang dihadapi selama proses belajar berlangsung, kendala yang dihadapi oleh peneliti adalah siswa ramai terutama siswa laki-laki. Selanjutnya, ketika pembelajaran menggunakan strategi Time Token pada tindakan I siswa kurang berani menjawab soal yang ada pada kupon. Kemudian ketika pembagian kelompok pada tindakan I, siswa sangat susah diarahkan, tidak menuruti perintah peneliti untuk berkumpul dengan kelompoknya, proses pembelajaran yang berlangsung menjadikurang efektif. Selanjutnya pada tindakan II siswa sudah mulai berani dalam menjawab soal dan suasana kelas sudah dapat dikondisikan dengan baik, dan semua siswa antusias dalam kegiatan pembelajaran hingga akhir pelajaran.

Upaya yang dilakukan oleh peneliti untuk mengatasi kendala yang dihadapi di dalam kelas yaitu dengan caramenegur langsung siswa yang ramai dan meroling tempat duduk (memisahkan dengan teman akrabnya supaya diskusi berjalan lancar), karena siswa yang ramai adalah siswa laki-laki. Peneliti juga memberikan motivasi kepada siswa yang malu-malu bahkan tidak berani mengutarakan jawabannya. Untuk pembagian kelompok selanjutnya peneliti dibantu teman sejawat untuk meyakinkan siswa berkumpul bersama kelompok yang telah dipilihkan peneliti. 


\section{PENUTUP}

Penerapan strategi Time Token pada penelitian dapat meningkatkan hasil belajar matematika siswa, maka dari hasil penelitian disimpulkan bahwa prosedur pembelajaran yang dikembangkan dalam penelitian ini berhasil sebagai suatu prosedur pembelajaran yang dapat membantu meningkatkan hasil belajar siswa kelas X SMKN 2 Singosari tahun pelajaran 2018/2019 pada materi matriks. Dari hasil penelitian yang peneliti lakukan diketahui bahwa hasil belajar matematika siswa kelas X SMKN 2 Singosari setelah mengikuti pembelajaran menggunakan strategi Time Token menunjukkan adanya peningkatan. Peningkatan hasil belajar siswa dapat dilihat dari perbandingan nilai awal siswa sebelum tindakan dengan tindakan I, dan tindakan II. Nilai rata-rata awal siswa sebelum tindakan, tindakan I dan tindakan II berturutturut adalah 66; 70,5; dan 80,5. Nilai tersebut adalah rata-rata secara klasikal. Sedangkan persentase ketuntasan belajar siswa pada pratindakan, tindakan I, dan tindakan II berturut-turut adalah sebesar $47,22 \%, 72,22 \%$ dan $86,1 \%$.

\section{DAFTAR PUSTAKA}

Abdullah, Ramli. 2012. Pembelajaran Berbasis Pemanfaatan Sumber Belajar. Jurnal Ilmiah Didaktika, 12 (2): 216-131.

Fahrudin Y.S.M. 2014. Penerapan Strategi Pembelajaran Time Token Untuk Meningkatkan Komunikasi Belajar Matematika. Jurnal FKIP UMS, 8(2): 1-11.

Hariyani, Sri. Kamunggul, Oni Lemba. 2019. Meningkatkan Hasil Belajar Materi Aritmetika Sosial Melalui Model Pembelajaran Teams Games Tournament. Prisma Sains: Jurnal Pengkajian Ilmu dan Pembelajaran Matematika dan IPA IKIP Mataram, 7(1): 1-9.

Huda, Miftahul. 2013. Model-model Pengajaran dan Pembelajaran. Yogyakarta: Pustaka Pelajar.

Kencana, Prasetiya. 2013. Penerapan Model Pembelajaran Kooperatif Tipe Tai Dipadukan dengan Time Token untuk Meningkatkan Kemampuan Berkomunikasi dan Hasil Belajar Kognitif Fisika Siswa SMA. Jurnal Pendidikan, 4(1): 22-34.

Latifah, Sri. 2014. Pengaruh Model Pembelajaran Kooperatif Tipe Time Token Berbantu Puzzle Terhadap Kemampuan Berfikir Kritis Peserta Didik Kelas X pada Materi Gelombang. Jurnal Pendidikan Fisika, 1(1): 13-23.

Nikmah, Wachidatun. 2012. Upaya Meningkatkan Keaktifan Siswa Dalam Pembelajaran Matematika Melalui Strategi Pembelajaran Time Token Arends 1998 Dengan Evaluasi Model Superitem Pada Pokok Bahasan Segitiga Dan Segiempat. Skripsi Diterbitkan. Surakarta: Universitas Muhammadiyah Surakarta.

Nugroho, Aji Arif dkk. 2017. Pengembangan Blog Sebagai Media Pembelajaran Matematika. Jurnal Pendidikan Matematika, 8 (2) :197-203.

Nurdyansyah. Toyiba, Fitriyani. 2018. Pengaruh Strategi Pembelajaran Aktif Terhadap Hasil Belajar Pada Madrasah Ibtidaiyah. Jurnal Nds dan Toy Fiks, 1(1): 45-60. 
Rusman. 2012. Belajar dan Pembelajaran Berbasis Komputer Mengembangkan Profesionalisme Guru Abad 21. Bandung: Alfabeta.

Suryani, Yeyen. Rosi, Asriani. 2014. Pengaruh Penggunaan Metode Pembelajaran Kooperatif Tipe Time Token Terhadap Hasil Belajar Siswa Kelas X SMA Negeri 1 Subang Kabupaten Kuningan. Jurnal Pendidikan, 10(19): 1-15. 